\title{
Molar teeth impaction on panoramic radiography
}

\author{
Fitri Hanifah Fudhla*, Nuskah Sudjana*, Lucky Riawan* \\ *Department of Oral and Maxillofacial Surgery Faculty of Dentistry Universitas Padjadjaran
}

\begin{abstract}
Introduction: The third molar are the most frequently impacted tooth. Characteristic of impacted third molar in every person may be different. Third molar are the last erupted tooth in dental arch and grow during the final period of growth, therefore third molar have the most potential for problems. The aim of this research are to know and to give description about third molar impaction based on the jaw location, classification, and complaint. Methods: This research was a retrospective observasional descriptive research. Population of this study are students of Dentistry Faculty of Padjadjaran University from class 2008. The sampling was incidentale. A total of 45 panoramic radiograph and the complaint questionaires based on pathological condition that associated with third molar impacted were observed. Classifications that used in this research were Pell and Gregory for the mandible, and Archer and Kruger for the maxilla. Results: This research shows that $62,8 \%$ of third molar are impacted. Based on jaw location, the third molar impaction most frequently occurs in the mandible $(66,35 \%)$ and region $4(33,65 \%)$. In the mandible, $81,58 \%$ are bilateral, $42,03 \%$ are mesioangular, 55,07\% are IIB Pell and Gregory classification. In the maxilla, $60 \%$ are $C$ position Archer and Kruger classification, $65,71 \%$ are sinus approximation, and $40 \%$ are mesioangular similar with distoangular. The most frequent complaint from pathological condition that associated with third molar impacted is local pain at third molar area $(75,6 \%)$. Conclusion: Third molar impaction most frequently occur in the mandible with mesioangular and IIB Pell and Gregory classification as the most frequently classification. The most frequent complaint from pathological condition that associated with third molar impacted is local pain at third molar area.
\end{abstract}

Keywords: Classification, complaint, and third molar impaction

\section{INTRODUCTION}

Third molar are unique teeth. Characteristics of third molar teeth include its eruption period is far from the time of eruption of other adult teeth and it is the last tooth to grow, therefore these teeth are often referred as wisdom teeth. This may be caused by the time of eruption of third molars during adult age, namely at 17-21 years. ${ }^{1}$ Third molar are the last teeth to erupt in the dental arch and grow during the final period of growth, therefore these teeth have greater potential for developing problems. A common problem with third molars is failure to erupt. The failure eruption of tooth into dental arch can cause impaction. Impaction can occur due to obstructed neighboring teeth, dense bone, and thick soft tissue. ${ }^{2}$ Impaction of the third molar may be also caused by lack of space in the jaw which prevent the tooth to erupt into the dental arch. Impaction can cause problems such as disturbance in masticatory system and if left undiagnosed 
can lead to potentially complications such as malocclusion, migration, loss of neighboring teeth, periodontal disease, resorption of adjacent tooth roots, pericoronitis, dentigerous cysts and odontogenic tumors3 (Miloro, 2004). In addition, impacted third molars can affect treatment in almost all fields in dentistry. ${ }^{4}$

Problems caused by impacted third molars including potential to cause complaints in patients, although there are not always exist complaints in people who experience impacted third molars. Complaints that arise in patients with impaction can be in the form of local pain due to infection, swelling, headaches, neck and ear tension and trismus. $^{5}$

Third molar is the most common teeth for impaction, and lower third molars are more prevalent (Miloro, 2004). Based on research conducted on dental student at University of Jember in 2008, the prevalence of impacted mandibular third molars on the students from Faculty of Dentistry in University of Jember during year 2003 was $41.67 \% .^{6}$

According to research conducted by Chusnul Chotimah Pattiasina in 1985, the occurrence of mandibular third molar impaction of the research subjects which is dental student from University of Indonesia (UI) reached half of the sample taken with a breakdown of the population of 500 students and a sample of 100 students. The type of impacted third molars can be different in each person and there is a classification of third molar impaction in maxilla and mandible.

The impaction classification are according to angulation or position of the third molar to the second molar, the relationship of the second molar with the anterior ramus of the mandible and the occlusal relationship to the lower jaw, and the relationship of the maxillary third molar with the maxillary sinus. However, there may be a dominant picture of each existing classifications.

According to research conducted by Retno Dwi in 2008, the classification of lower third molar impaction of dental student from University of Jember in 2003 are based on the Dental Relationship with Ramus Mandibula and Second Molar, Class II was the highest grade $(70 \%)$, based on the Depth of the Lower Molar Third Molar Buried in the Jawbone, level A is the highest level (62.5\%), and based on the Vertical Axis Angulation of the Lower Molar Third Tooth to the Vertical Axis of the Second Molar, the mesioangular is the highest prevalence $(52,5 \%){ }^{7}$

The available researches mostly focus on the lower third molar, whereas research that discusses the overall impact of the third molar on both the maxilla and the mandible is rare. Therefore, the authors are interested in discussing the type of third molars impaction from both upper and lower jaw which have not been discussed in these studies which related to the jaw, classification, and type of complaint that occurred.

The author select dental students from class 2008, Padjadjaran University (UNPAD) as the object of research because the age of dental students from class of 2008 was in the eruption of third molars, data on the description of third molars impaction on dental students Padjadjaran University class 2008 did not exist, and this type of research had never been conducted. In addition, the limitations of the writer both in time and place are also one of the considerations.

The purpose of this study was to obtain data and provide a picture of impacted third molars in dental students class of 2008 Padjadjaran University (UNPAD) based on the location of their jaws through panoramic radiographs, images of impacted third molar teeth of dental students based on their classification through panoramic radiographs, impact images third molar teeth based on the type of complaint through a questionnaire.

\section{METHODS}

This was a retrospective descriptive observational study which conducted with purpose of overview the characteristics of the third molars impaction in dental students' class of 2008 UNPAD in form of tables and percentages. Descriptive research methods aim to show the phenomena that occur within a particular population. ${ }^{8}$

The population of this study were all the dental student's class 2008 from UNPAD. The sample in this study was obtained through the incidental sampling method.

The inclusion criteria of sample were the sample who had photographed panoramic at the age of more than 17 years, third molars had never been extracted after a panoramic photograph, 
and were willing join this research. The larger the sample taken in the study, the less likely there is the possibility of being wrong in drawing conclusions about the population. According to Bailey (1982), the smallest samples of size should be 30 subjects if the research uses statistical data analysis. ${ }^{9}$

The alternative determination of sample size according to Fraenkel and Wallen (1993) is dependent on the type of research. For descriptive research, the minimum recommended sample is $10 \%$ of the population 10 (Kasjono, 2009). Another suggestion from Roscoe (1982) regarding sample size for research is the decent sample size is between $30-500 .^{11}$

Data analysis techniques by collecting and classifying the images are obtained according to the problem identification. After that, the data is processed manually by calculating the frequency distribution in the form of a percentage, compiled simply, and presented in tables and diagrams, and then analyzed descriptively.

\section{RESULTS}

Table 1. Frequency Distribution of Characteristics of Third Molar Teams Samples from Panoramic Radiography Photographs Based on the State of Third Molar Teeth

\begin{tabular}{ccc}
\hline Third Molar Condition & F & $\%$ \\
\hline Impaksi & 104 & 62,80 \\
Erupsi sempurna & 60 & 27,44 \\
Tidak ada benih & 16 & 9,76 \\
\hline Total & 180 & 100
\end{tabular}

This research was conducted by classifying third molar impaction based on jaw location, classification, and type of complaints through panoramic photo observations and filling questionnaire complaints on 45 dental students of Padjadjaran University class of 2008 who met the criteria for sampling criteria of 103 people in the entire population.

The number of dental students of Padjadjaran University class of 2008 who had been photographed panoramic was 61 students, but only 45 students who fit the inclusion criteria in this study. The reason 45 people took these different panoramic photographs. The reasons for the sample being photographed by panoramic radiography include consideration of odontectomy, observe state of third molars, experiencing complaints related to impacted third molars, for the purpose of extracting teeth, for the benefit of endodontic treatment, and for the benefit of orthodontic treatment.

The results of the questionnaire, which were distributed to 45 samples, namely dental students Padjadjaran University in 2008 who met the criteria for sampling, showed that the majority of the sample as many as 34 people $(75.6 \%)$ were women while the rest were 11 men (24, 4\%). By age, information was obtained that nearly half of the samples studied were 21 years $(46.7 \%)$ and 22 years (44.4\%) and very few were 20 years $(2.2 \%)$ and 23 years $(6.7 \%)$. The average age of the sample in this study was 21.56 years.

Tabel 2. Distribusi Frekuensi Karakteristik Sampel dari Foto Radiografi Panoramik Berdasarkan Status Impaksi Gigi Molar Tiga

\begin{tabular}{crr}
\hline Keadaan Impaksi Gigi Molar Tiga & F & $\%$ \\
\hline Impaksi & 40 & 88,89 \\
Tidak impaksi & 5 & 11,11 \\
\hline Total & 45 & 100 \\
\hline
\end{tabular}

Table 2 contains sample characteristics based on the impact status of third molars. The number of samples that experienced an impact was 40 samples or $88.89 \%$ and only 5 samples or $11.11 \%$ did not experience the impact.

Illustration of Third Molar Tooth Impaction of dental student from Unpad batch 2008. Based on Jaw Location, the authors present the results of research on the description of impacted third molars on dental student Unpad batch 2008, who fit the sampling criteria, based on the location of the impact.

Tabel 3. Distribusi Frekuensi Sampel yang Mengalami Impaksi Gigi Molar Tiga dilihat dari Foto Radiografi Panoramik Berdasarkan Letak Rahang

\begin{tabular}{ccc}
\hline Letak Rahang & F & $\%$ \\
\hline Rahang Atas & 2 & 5,00 \\
Rahang Bawah & 17 & 42,50 \\
Rahang Atas dan Rahang Bawah & 21 & 52,50 \\
\hline Total & 40 & 100 \\
\hline
\end{tabular}

Table 3 shows the distribution of samples affected by third molars based on the location of the jaw. The table shows the data that the impact of third 
molars on the dental students Unpad year 2008 was mostly in the two jaws, as many as 21 samples, followed by the lower jaw as many as 17 samples, and in the upper jaw as many as 2 samples.

Tabel 4. Distribusi Frekuensi Impaksi Gigi Molar Tiga Berdasarkan Letak Rahang

\begin{tabular}{ccc}
\hline Letak Rahang & F & $\%$ \\
\hline Rahang Atas & 35 & 33.65 \\
Rahang Bawah & 69 & 66.35 \\
Total & 104 & 100 \\
\hline
\end{tabular}

Table 4 shows the results of $66.35 \%$ of the lower third molars impaction from dental students batch 2008 Unpad and $33.65 \%$ of the impacted third molars were in the upper jaw.

Tabel 5. Distribusi Frekuensi Impaksi Gigi Molar Tiga Berdasarkan Letak Regio

\begin{tabular}{ccc}
\hline Letak Regio & F & $\%$ \\
\hline Regio 1 & 20 & 19,23 \\
Regio 2 & 15 & 14,42 \\
Regio 3 & 34 & 32,70 \\
Regio 4 & 35 & 33,65 \\
\hline Total & 104 & 100 \\
\hline
\end{tabular}

Table and diagram 5 show the number of impacted third molars located in region three with those in region four almost the same, ie 34 in region three and 35 in region four. A total of 20 impacted third molars are located in region one and the least number is in region two, which is 15 .

Tabel 6. Distribusi Frekuensi Impaksi Gigi Molar Tiga Berdasarkan Letak Sisi Rahang

\begin{tabular}{ccccc}
\hline Sisi Rahang & \multicolumn{2}{c}{ Rahang Atas } & \multicolumn{2}{c}{ Rahang Bawah } \\
\hline & $\mathrm{f}$ & $\%$ & $\mathrm{f}$ & $\%$ \\
\hline Unilateral & 11 & 47,83 & 7 & 18,42 \\
Bilateral & 12 & 52,17 & 31 & 81,58 \\
\hline Total & 23 & 100 & 38 & 100 \\
\hline
\end{tabular}

Table 6 shows that based on the location of the side of the jaw, the number of third molars experiencing bilateral impact was the most, both in the maxilla and the mandible, which was $52.17 \%$ in the maxilla and $81.58 \%$ in the mandible. Whereas third molars which experienced unilateral impact were only $47.83 \%$ in the maxilla and $18.42 \%$ in the mandible. Illustration of Third Molar Tooth Impaction of dental student Unpad batch 2008 Class based on Classification. Authors present the results of research on the description of impacted third molars of dental students Padjadjaran University batch 2008, who fit the sampling criteria.

Tabel 7. Distribusi Frekuensi Impaksi Gigi Molar Tiga Rahang Bawah Berdasarkan Klasifikasi Pell \& Gregory

\begin{tabular}{cccc}
\hline Kelas & Posisi & F & $\%$ \\
\hline \multirow{3}{*}{ Kelas I } & A & 3 & 4.35 \\
& B & 1 & 1.45 \\
\multirow{3}{*}{ Kelas II } & C & 1 & 1.45 \\
& A & 23 & 33.33 \\
\multirow{3}{*}{ Kelas III } & B & 38 & 55.07 \\
& C & 1 & 1.45 \\
& A & 0 & 0 \\
& B & 0 & 0 \\
& C & 2 & 2.9 \\
\hline
\end{tabular}

Table 7. shows the classification based on the Pell \& Gregory, the number of tooth impaction classifications with the highest percentage is class IIB, which is $55.07 \%$, more than half the number of third molars of the sample. Then followed by class IIA at $33.33 \%$, then class IA at $4.35 \%$, class IIIC at $2.9 \%$, and the smallest percentage were IB, IC, and IIC classes at $1.45 \%$. Class IIIA and IIIB were not found in this study.

Tabel 8. Distribusi Frekuensi Impaksi Gigi Molar Tiga Berdasarkan Angulasinya Menurut Klasifikasi Archer dan Kruger

\begin{tabular}{ccccc}
\hline Angulasi & \multicolumn{2}{c}{ Rahang Atas } & \multicolumn{2}{c}{ Rahang Bawah } \\
\hline & f & $\%$ & f & $\%$ \\
\hline Mesioangular & 14 & 40,00 & 29 & 42,03 \\
Distoangular & 14 & 40,00 & 4 & 5,80 \\
Vertikal & 7 & 20,00 & 8 & 11,59 \\
Horizontal & 0 & 0 & 24 & 34,78 \\
Buccoangular & 0 & 0 & 4 & 5,80 \\
Linguoangular & 0 & 0 & 0 & 0 \\
Inverted & 0 & 0 & 0 & 0 \\
\hline Total & 35 & 100 & 69 & 100 \\
\hline
\end{tabular}

Table 8. shows the same percentage between classifications based on mesioangular and distoangular angulations in the maxilla, which is equal to $40 \%$, followed by vertical angulation at $20 \%$. Horizontal, buccoangular, linguoangilar, and 
inverted angulation were not found in the maxilla. In the lower jaw, the most common type of angulation is mesioangular angulation of $42.03 \%$, almost half of the number of mandibular third molars of the sample, followed by horizontal angulation $34.78 \%$, then vertical of $11.59 \%$, and those with the least occurred namely distoangular and buccoangular at 5.80\%. Linguoangular and inverted angulations were not found in this study.

Tabel 9. Distribusi Frekuensi Impaksi Gigi Molar Tiga Rahang Atas Berdasarkan Kedalamannya dalam Tulang Menurut Klasifikasi Archer dan Kruger

\begin{tabular}{ccc}
\hline Posisi & F & $\%$ \\
\hline A & 0 & 0 \\
B & 13 & 37,14 \\
C & 21 & 60,00 \\
D & 1 & 2,86 \\
E & 0 & 0 \\
\hline Total & 35 & 100 \\
\hline
\end{tabular}

Table 9 shows the number of positions that most frequently occur is position C, which is $60 \%$, followed by position B $37.14 \%$, and the least occurring is position $D$, which is $2.86 \%$. Position $A$ and $E$ were not found in this study.

Tabel 10. Distribusi Frekuensi Impaksi Gigi Molar Tiga Rahang Atas Berdasarkan Hubungannya dengan Sinus Maksilaris Menurut Klasifikasi Archer dam Kruger

\begin{tabular}{ccc}
\hline Hubungan Dengan Sinus Maksilaris & F & $\%$ \\
\hline Sinus Approximation & 23 & 65,71 \\
Sinus Non Approximation & 12 & 34,29 \\
\hline Total & 35 & 100 \\
\hline
\end{tabular}

Table 10 shows that based on the relationship of maxillary third molars with maxillary sinus, third molars that fall into the Sinus Approximation classification account for more than half the number of maxillary third molars of the sample, which is 23 upper third molars or $65.71 \%$. While those included in the Sinus Non Approximation classification were 12 maxillary third molars, or $34.29 \%$.

Table 11 above shows the most felt complaint from impacted third molars is the presence of pain complaints in the third molar area $(75.6 \%$ of the sample). The pain that was experienced the most was on a somewhat disturbing scale $(58.8 \%)$, as little as $29.4 \%$, and only $2.9 \%$ were classified as very disturbing and unbearable. Second highest frequency are complaints of swelling in the area of third molars (48.9\%), and the smallest frequency is having experienced headaches with no apparent cause $(40 \%)$. Percentage of headaches with no specific cause, of the 18 samples that experienced them, as many as half felt pain that was classified as somewhat annoying (50\%), almost a quarter (22.2\%) had a slight pain and less than $20 \%$ each felt in the category of very disturbing (16.7\%) and disturbing activities (11.1\%). Other complaints experienced include food impaction, bleeding gums around the third molar, uncomfortable opening the mouth, mouth sores, and cheeks that are often bitten.

\begin{tabular}{|c|c|c|c|c|}
\hline \multirow{2}{*}{ Keluhan } & \multicolumn{2}{|c|}{ Ya } & \multicolumn{2}{|c|}{ Tidak } \\
\hline & $f$ & $\%$ & $f$ & $\%$ \\
\hline $\begin{array}{c}\text { Gigi molar tiga belum } \\
\text { erupsi }\end{array}$ & 12 & 26,7 & 33 & 73,3 \\
\hline $\begin{array}{l}\text { Daerah gigi molar tiga } \\
\text { pernah mengalami } \\
\text { bengkak }\end{array}$ & 22 & 48,9 & 19 & 42,2 \\
\hline $\begin{array}{l}\text { Daerah gigi molar tiga } \\
\text { pernah mengalami sakit }\end{array}$ & 34 & 75,6 & 11 & 24,4 \\
\hline Sedikit sakit (2) & 10 & 29,4 & & \\
\hline Agak mengganggu (4) & 20 & 58,8 & & \\
\hline Mengganggu Aktivitas (6) & 2 & 5,9 & & \\
\hline Sangat mengganggu (8) & 1 & 2,9 & & \\
\hline Tak tertahankan (10) & 1 & 2,9 & & \\
\hline $\begin{array}{l}\text { Pernah mengalami nyeri } \\
\text { kepala yang tidak jelas } \\
\text { penyebabnya }\end{array}$ & 18 & 40,0 & 27 & 60,0 \\
\hline Sedikit sakit (2) & 4 & 22,2 & & \\
\hline Agak mengganggu (4) & 9 & 50,0 & & \\
\hline Mengganggu Aktivitas (6) & 2 & 11,1 & & \\
\hline Sangat mengganggu (8) & 3 & 16,7 & & \\
\hline $\begin{array}{l}\text { Keluhan lain yang pernah } \\
\text { dirasakan selain yang } \\
\text { telah disebutkan di atas }\end{array}$ & 22 & 48,9 & 23 & 51,1 \\
\hline
\end{tabular}

\section{DISCUSSION}

The results of the study in table 2 showed that obtained data are 40 people or $88.89 \%$ of dental students class of 2008 Padjadjaran University, which in accordance with the sampling criteria 
had an impact. This large result might be due to the small number of samples, besides that one of the inclusion criteria for a sample is presence of a panoramic radiograph and may due to complaints caused by impaction, or as a condition to be done odontectomy so the results of his study showed a large percentage of impacted third molars.

In addition, genetic factors may also play a role in causing impaction. According to Mendel's theory, if one of the parent has a small jaw, and one other parent has a large tooth, their children is likely to have a small jaw and a large tooth. As a result of this condition, there can be a shortage of permanent tooth eruption sites resulting in an impact. However, in this study (represented in questionnaire questions) genetic factors and Mendel's theory were not observed.

According to Goldberg quoted by Tridjaja, panoramic photographs of 5600 patients aged between 17-24 years made in 1971, 65.6\% had at least one impacted tooth. The study shows that the percentage is almost high even though the comparison of the number of samples is very high. Another study said $65 \%$ of the third molars of patients who came to the Orthodontics in Dhule, India, had an impact. However, the results of this study shown in table 2 are much higher than other studies, which stated that only $27.8 \%$ of third molars in 7486 Hong Kong Chinese populations were affected where the age of the studied population ranged from 17-89 years with age the average population studied was 39.6 years. ${ }^{12}$

The concept of Hunter-Enlow growth balance is an important principle in the development of facial bones. Each individual component of the skull bone develops in various directions so that the components must be able to react directly to compensate for various growth activities. This was achieved with the balance of growth occurring in the opposite direction.

This growth balance coordinates the different movements of the cranial base, nasomaxillary complex, and mandible, which are both developing, and also adapts changes in relation to the components of the skull. Disruption during the relation of the growth pattern results in craniofacial anomalies. The disorder can be related to disproportion of balance in both the vertical and horizontal planes.
According to this study, from the number of samples of dental students Padjadjaran University year 2008 written in table 3, it was found that based on its location, impacted third molars most often occur in both jaws $52.5 \%$, followed by the lower jaw only $42.5 \%$, and most rarely occurs in the maxilla only $5 \%$. The results of the study where the largest percentage of impacted third molars occur in both the maxilla and mandible may be due to this growth balance concept. The results of these studies differ from the results of studies conducted on the Saudi population in 2010 which stated that the most impaction was the lower jaw (53.1\%), followed by the upper jaw only $(31.8 \%)$, and the least occurred in both jaws (15.1\%). This might be due to different races and sample populations and different sample ages. ${ }^{13}$

The cause of the increased impact of mandibular third molars is due to lack of space for eruption. This can be explained by the type of food consumed is generally soft, so digesting does not require strong work of the masticatory muscles, whereas masticatory stimulation is a stimulus for jaw growth so the lack of stimulus causes the lower jaw to become less developed4.3 (Wagner and Tetsch, 1982; Miloro, 2004), in newborns, the location of the ramus is at the location where the first primary molars will erupt.

Progressive posterior remodeling creates space for the eruption of deciduous second molars and subsequently for eruption of permanent molar teeth. However, this growth is often stopped before enough space is formed for the eruption of permanent third molars, which is impacted in ramus. ${ }^{14}$ The mandible grows and develops into thick, dense bone, while one of the etiologies of impaction is bone density on it or around it. This might be one of the factors causing the large impact frequency of third molars in the mandible.

Mandibular third molars are the most impacted teeth. It must be understood the development and movement of mandibular third molars at the age of 7-25 years to determine the cause of the high incidence of impaction in mandibular third molars. Several studies have discussed a lot of patterns of development and eruption of third molars. The tooth bud of the mandibular third molars can be seen radiographically at the age of 9 years, and cusp mineralization is completed about 2 years 
afterwards. At the age of 11 years, the third molar teeth are inside the anterior border of the ramus with the occlusal surface facing almost anteriorly. The depth of the tooth bud is around the occlusal plane of the erupted teeth. Crown formation is usually completed by the age of 14 years, and about $50 \%$ of the roots are formed at the age of 16 years. At that time, the mandible grows in a long direction and there is extensive resorption at the anterior border of the ramus.

The occurrence of this process mentions the position of the third molar with the next second molar changing, assuming the position of the third molar is around the root of the second molar, besides the crown angulation becomes more horizontal. The roots with an open apex are fully formed at the age of 18 years. By the age of $24,95 \%$ of all erupted third molars have been completely erupted.

Changes in occlusal surface orientation from anterior inclination to vertical inclination occur at the time of root formation. At that time, the teeth rotate from angulation. The concept of Hunter-Enlow growth balance is an important principle in the development of facial bones. Each individual component of the skull bone develops in various directions so that the components must be able to react directly to compensate for various growth activities. This was achieved with the balance of growth occurring in the opposite direction.

This growth balance coordinates the different movements of the cranial base, nasomaxillary complex, and mandible, which are both developing, and also adapts changes in relation to the components of the skull. Disruption during the relation of the growth pattern results in craniofacial anomalies. The disorder can be related to disproportion of balance in both the vertical and horizontal planes.

According to this study, from the number of samples of dental students batch 2008 Padjadjaran University written in table 3 , it was found that based on its location, impacted third molars most often occur in both jaws (52.5\%), followed by the lower jaw only (42.5\%), and most rarely occurs in the maxilla only $(5 \%)$. The results of the study where the largest percentage of impacted third molars occur in both the maxilla and mandible may be due to this growth balance concept. The results of these studies differ from the results of studies conducted on the Saudi population in 2010 which stated that the most impaction was the lower jaw (53.1\%), followed by the upper jaw only $(31.8 \%)$, and the least occurred in both jaws (15.1\%). This might be due to different races and sample populations and different sample ages. ${ }^{13}$

The cause of the increased impact of mandibular third molars is due to lack of space for eruption. This can be explained, among other things, the type of food consumed is generally soft, so digesting does not require strong work of the masticatory muscles, whereas masticatory stimulation is a stimulus for jaw growth so the lack of stimulus causes the lower jaw to become less developed. ${ }^{4,3}$, in newborns, the location of the ramus is at the location where the first primary molars will erupt. Progressive posterior remodeling creates room for the eruption of deciduous second molars and subsequently for eruption of permanent molar teeth. However, this growth is often stopped before enough space is formed for the eruption of permanent third molars, which is impacted in ramus. ${ }^{14}$

The mandible grows and develops into thick, dense bone, while one of the etiologies of impaction is bone density on it or around it. This might be one of the factors causing the large impact frequency of third molars in the mandible. Mandibular third molars are the most impacted teeth. It must be understood the development and movement of mandibular third molars at the age of 7-25 years to determine the cause of the high incidence of impaction in mandibular third molars. Several studies have discussed a lot of patterns of development and eruption of third molars.

The seeds of the mandibular third molars can be seen radiographically at the age of 9 years, and cusp mineralization is completed about 2 years afterwards. At the age of 11 years, the third molar teeth are inside the anterior border of the ramus with the occlusal surface facing almost anteriorly. The depth of the tooth seed is around the occlusal plane of the erupted teeth. Crown formation is usually completed by the age of 14 years, and about $50 \%$ of the roots are formed at the age of 16 years. At that time, the mandible grows in a long direction and there is extensive resorption at the anterior border of the ramus. 
The occurrence of this process mentions the position of the third molar with the next second molar changing, assuming the position of the third molar is around the root of the second molar, besides the crown angulation becomes more horizontal. The roots with an open apex are fully formed at the age of 18 years. By the age of $24,95 \%$ of all erupted third molars have been completely erupted.

Changes in occlusal surface orientation from anterior inclination to vertical inclination occur at the time of root formation. At that time, the teeth rotate from angulation by $47.83 \%$. Research on the maxilla supporting this study is still rare. Based on the Pell \& Gregory classification in table 7 , the class most commonly found is class IIB of $55.07 \%$, more than half of the mandibular third molars in the sample. The second highest class is class IIA 33.33\%.

Class II Pell \& Gregory classification shows the distance of the anterior border of the ramus with the distal portion of the second molar is smaller than the mesiodistal width of the third molar, according to the etiology of the most common impaction occurrence, namely the lack of space for eruption of the third molar where the arch length is smaller from the long dental arch which does not allow the third molar to erupt.

The results of this study are in accordance with previous studies which stated that the most classes according to the Pell \& Gregory classification are class IIB, followed by class IIA. The results obtained from previous studies are smaller than this study, which is $38.5 \%$ for class IIB, and $18.8 \%$ for class IIA15 (Sanjit, 2011). However, this study obtained smaller results from the results of research conducted at the FKG University Jember students in class of 2003 despite having the same number of classes.

According to the study, the most classes were class II by $70 \%$, and position A by $62.5 \%$. Table 8 shows angulation of impacted mandibular third molars which is most common in this study is mesioangular at $42.03 \%$, followed by horizontal angulation at $34.78 \%$. These results are consistent with Peterson's statement that the third molar begins its development in the horizontal direction, then as the teeth develop and jaw growth, the angulation changes from horizontal to mesioangular and then vertical, and impaction occurs often due to failure of rotation from mesioangular to vertical angulation.

The results of the study listed in table 8 differ from the results of Singh Sanjit's (2011) study which states that the most angulations are vertical $(40.1 \%)$, followed by mesioangular $(33.3 \%)$ 15. However, the results of this study are the same as those of Retno Dwi (2008) on the dental student University Jember class of 2003 which stated that the highest number of angulations was mesioangular at $52.5 \%{ }^{7}$

The results of this study are greater than the results of this study 16 . The similarity between the results of this study and those conducted by Retno Dwi (2008) might be due to the characteristics of the same sample, namely students, where the age factor is almost the same compared to the characteristics of Singh Sanjit's (2011) sample which is more varied7,15. The distribution of impaction classification of maxillary third molars based on table 9 most occurs at position C of $60 \%$. This result is different from research conducted by Ali $\mathrm{H}$ in 2010, where in the study the most position was position B of $48.2 \%$.

Research and explanations that support the results of this study are still difficult for writers to find. In table 8 , the distribution of impact angulation of mesioangular and distoangular maxillary third molars is the same, which is $40 \%$. This is different from the results of Ali H's study which states that the angulation of the most impacted third molars in the maxilla is vertical at $49.6 \%$, followed by a distoangular at $25.4 \%$. The results of this study are also different from the statement of one of the journals that states that the angulation of impacted third molars is the most common is vertical angulation. ${ }^{16}$

Based on table 10, which entered into the sinus approximation classification was $65.71 \%$ or as many as 23 third molars out of 35 maxillary third molars. Previous studies on maxillary classification based on the relationship of third molars with maxillary sinus in accordance with this study were not found, but there are studies that state that SA cases are more common in men by $64.7 \%$, while NSA is more common in women by $65,2 \%$. Palatal vault remodeling (which also includes the base of the nose) moves it in the same direction (downward); where at the base of the nose resorption occurs and in the palate there 
is an increase. ${ }^{14}$

Maxillary growth causes an increase in the size of the maxillary sinus. The maxillary sinus can vary greatly in size and shape due to the external morphology of the surrounding bone and nearby teeth. In adults, the location of the sinuses starts from the area of the canines or first premolars to the back of the molar or posterior wall maxillary tuberosity. ${ }^{17}$ The increase in sinus size along with the growth of the maxilla and the pattern of maxillary remodeling that is resorbed at the base of the nose and the addition of the palate are factors that might cause the number of third molars to enter the Sinus Approximation classification.

Table 11 shows the results that the most common type of complaint of impacted third molars in this study was the presence of pain complaints in the area of third molars $175.6 \%$ of the sample). For this complaint, the pain that was experienced most was on a somewhat disturbing scale $(58.8 \%)$, the least pain was $29.4 \%$, and only $2.9 \%$ were classified as very disturbing and unbearable. Complaints with the second highest frequency are complaints of swelling in the area of third molars (48.9\%). These results are in accordance with the research of Chu FCS, et al (2003) which states that the number of complaints that most often occur are complaints of pain and swelling. ${ }^{12}$

Nearly a century ago, impacted teeth sometimes caused both acute and chronic complaints, the symptomatic complaints first occurred in the retromolar region of the lower jaw and the maxilla which when spreaded could cause complaints that could interfere with patient activity18 (Lukman, 2004). The statement turned out to be in accordance with the results of this study which says the most complaints are pain in the third molars. The smallest frequency of complaints in this study was complaints of headache that was not clearly caused by third molars (40\%). Specifically for headaches that are not clearly caused by third molars, of the 18 samples that experienced them, as many as half felt pain that was classified as somewhat annoying (50\%), almost a quarter (22.2\%) had a slight pain and less than $20 \%$ each felt deep the category is very disturbing (16.7\%) and disturbing the activity (11.1\%). Other complaints experienced include food impaction, bleeding gums around the third molar, uncomfortable opening the mouth, mouth sores, and cheeks that are often bitten. Complaints of food impaction and bleeding gums were also found in the study of Chu FCS, et al conducted on the Hong Kong Chinese population in 2003.

\section{CONCLUSION}

Impaction of the third molar is most common in the lower jaw and region 4. Impaction of the maxillary third molar and bilateral impacted third molar. Type of classification in the lower jaw, class IIB Pell and Gregory classification is the highest number of classes including mesioangular angulation. The maxilla, according to Archer and Kruger's classification, the most impaction occurs at position.

\section{DAFTAR PUSTAKA}

1. Mac Gregor JT. Cumulated Indexs Medicus. 1985. Food Chem Toxicol 1985 Dec:23(12):1041-7

2. Peterson LJ. Contemporary Oral and Maxillofacial Surgery, $4^{\text {th }}$ ed. Mosby Yearbook Inc. 2003. 184; 185; 188; 189 pp.

3. Miloro M. Peterson's Principles of Oral and Maxillofacial Surgery, $2^{\text {nd }}$ ed. Hamilton: BC Decker Inc. 2004. 132 - 133; 139 - 140 pp.

4. Tetsch P, Wagner W. Pencabutan Gigi Molar Ketiga. EGC: Jakarta. 1992. 1 pp.

5. Chumaeroh S. Beberapa Faktor yang Mempengaruhi Keluhan pada Impaksi Molar Tiga Bawah. 2003. (http: / /www.mediamedika. net/archives/187) (diakses 21 Februari 2012)

6. Scherstén E, Lysell L, Rohlin M. Prevalence of impacted third molars in dental students. Swed Dent J. 1989;13(1-2):7-13.

7. Prasetyaningtyas RD. Prevalensi Dan Klasifikasi Impaksi Gigi Molar Ketiga Rahang Bawah Pada Mahasiswa Fakultas Kedokteran Gigi Universitas Jember Angkatan Tahun 2003. Skripsi. Jember: FKG UNEJ. 2008.

8. Notoadmodjo S. Metodologi Penelitian Kesehatan. Jakarta: Rineka Cipta. 2010.

9. Ruslan, Rosadi. Meode Penelitian : Public Relations dan Komunikasi. Jakarta: Raja Grafindo Persada. 2006. 149 pp.

10. Kasjono, Subaris H, Yasril. Teknik Sampling 
untuk Penelitian Kesehatan. Yogyakarta: Graha Ilmu. 2009. 129 pp.

11. Sugiyono. Statistika untuk Penelitian. $1^{\text {st }}$ ed. Alfabeta : Bandung. 2011. 74 pp.

12. Chu FC, Li TK, Lui VK, Newsome PR, Chow RL, Cheung LK. Prevalence of impacted teeth and associated pathologies-a radiographic study of the Hong Kong Chinese population. Hong Kong Med J. 2003 Jun;9(3):158-63.

13. Hassan AH. Pattern of Third Molar Impaction in a Saudi Population. Clin Cosmet Investig Dent. 2010; 2: 109-113. DOI: 10.2147/CCIDEN. S12394

14. Proffit, William R. Contemporary Orthodontics. $4^{\text {th }}$ ed. St. Louis : Mosby. 2007. 45-47 pp. https://www.worldcat.org/title/ contemporary-orthodontics/oclc/769189433
15. Bernstein BJ, Chaterjee S. Progress in Cryptology INDOCRYPT. $12^{\text {th }}$ ed. International conference on crypthology in india chennai, India, December 2011, Proceedings. 2011. DOI: 10.1007/978-3-642-25578-6

16. Fardi A, Kondylidou A, Bachour Z, Parisis N. Incidence of impacted and supernumerary teeth - A radiographic study in a North Greek population. Medicina oral, patologia oral $y$ cirugia bucal. January 2011;16(1):e56-61. DOI: $10.4317 /$ medoral.16.e56

17. Linden Vd. Facial Growth and Facial Orthopedics. UK : Quintessence Publishing. 1986. 73; $82 \mathrm{pp}$.

18. Lukman D. Penentuan Lokasi Roentgnografi Gigi Impaksi. J Ind Dent Assoc. 2004;3(2):10 -13 . 